\title{
島根半島周辺地域に自生するハマボウフウに関する研究 一自生状況，フェノロジーならびに冷湿処理下の胚の発達について一
}

\author{
石原美香 ${ }^{1} \cdot$ 小林伸雄 ${ }^{1 *} \cdot$ 坂本咲子 ${ }^{1} \cdot$ 石橋正美 ${ }^{2 \mathrm{a}}$ \\ ${ }^{1}$ 島根大学生物資源科学部 690-8504 島根県松江市西川津町 1060 \\ 2 島根県立出雲農林高等学校 693-0046 島根県出雲市下横田 950
}

\section{Native Habitat, Phenology and Embryo Development of Glehnia littoralis Fr. Schm. in Areas Surrounding Shimane Peninsula, Japan}

\author{
Mika Ishihara ${ }^{1}$, Nobuo Kobayashi ${ }^{1 *}$, Sakiko Sakamoto ${ }^{1}$ and Masami Ishibashi ${ }^{2 a}$ \\ ${ }^{1}$ Faculty of Life and Environmental Science, Shimane University, Matsue, Shimane 690-8504 \\ ${ }^{2}$ Shimane Prefectural Izumo-nourin High School, Izumo, Shimane 693-0046
}

\begin{abstract}
The native habitat, phenology and embryo development of Glehnia littoralis Fr. Schm distributed in areas surrounding Shimane Peninsula, Japan were investigated in order to facilitate preservation of natural habitats and develop herb applications as a local genetic resources of this plant. Several wild populations of G. littoralis were found in the sandy beach areas of Yumigahama (Yonago, Tottori pref.), Iwami-Kaihin Park (Hamada, Shimane pref.) and other beaches. The protection and increase of G. littoralis population has been promoted in the beaches of Yumigahama and Sotozono (Izumo, Shimane pref.). In the wild habitat of this plant, the following phonological events were observed: Foliation from the end of Feb., flower bud emergence from the mid Apr., flowering from early May to mid Aug., fruit development, maturation and abscission at the peduncle from early July, leaf yellowing and abscission from Sep. and dormancy from the beginning of Dec. Embryos in the seeds began to enlarge under cold stratification for fifty days. GA treatment and removal of pericarp also promoted embryo development and germination.
\end{abstract}

Key Words : cold stratification, embryo development, germination, wild habitat protection

キーワード : 肧発育, 発芽, 自生地保護, 冷湿処理

\section{緒 言}

ハマボウフウ（Glehnia littoralis Fr. Schm.）は，日本原産 のセリ科ハマボウフウ属の多年生海浜植物で, 北海道から 沖縄までの日本各地の砂浜に自生し，5～6 月頃に複散形 花序の白い花を咲かせる. 葉身は厚く光沢があり, 葉身お よび葉柄は独特の芳香を有することから, つま物として利 用するほか，吸い物，茶碗蒸し，ひたし物や酢の物に供さ れる. 日本では平安時代から食品および薬草として野生品 が利用され，江戸時代には「八百屋防風」の名前で市販さ れた記録が残っている. 古くから根を漢方薬として発汗, 鎮痛, 解熱薬に用いるほか, 現在では若い茎葉の軟化栽培 が埼玉県と愛知県を中心に行われている（青葉, 2000; 峰 岸，1989; 成川，2001; 小野，1991). 一方, 島根県では昭和

2007 年 8 月 7 日 受付. 2008 年 3 月 17 日 受理.

* Corresponding author. E-mail: nkobayashi@life.shimane-u.ac.jp

a 現在 : 島根県立益田翔陽高等学校
60 年からハマボウフウを特産作物として導入後，現在では 松江市八束町で拈もに関西方面向けに商業生産が行われて いる。な拉，近年では八マボウフウの茥葉に高い抗酸化性 のあることが報告されており，その機能性が注目されてい る（池羽・鹿島, 2006).

しかし，八マボウフウの自生地は海岸砂丘の減少や人為 的な乱獲のために，日本各地で急速に減少している（白井 ら，1999）。陰地方の海岸地域では，おもに春期に自生す るハマボウフウの茥葉を採集し，酢味増あえなどで食す食 文化が残って扣り（日本の食生活全集鳥取編集委員会， 1991），当地域に打いて子，乱獲による自生地の減少が問題 となっている. そのため, 島根県出雲地域では地元の出雲 農林高等学校と地域自治団体等により, 自生地の保護と組 織培養等を用いた種苗の増殖が行われている.

ハマボウフウに関する研究では，栽培に拉いて種子の発 芽率が低く不斉一であることが問題とされ，これを克服す る方法としては，発芽特性と果皮剥皮処理あるいは冷湿処 理による発芽率の改善に関する報告（村井・吉田，1991） 
や，ジベレリン（以下 GA）による発芽改善に関する報告 （白井ら，1999）がある. また, 受粉様式に関する報告（伊 藤ら，1996）はあるが, 自生地でのフェノロジーや種子の 発芽に至るまでの肧の発達については知られていない.

本研究では, 山陰地域に打けるハマボウフウの自生地の 保護活動を推進するとともに, 地域活性化を目的とした本 種の地域特産資源としての活用や特産品の開発の基礎研究 として，本地域に扣ける詳細な自生状況の調査とフェノロ ジ一観察を行った。 また，フェノロジ一調査の一部として ハマボウフウの生育サイクルを把握するために, 冷湿処理 下に打ける発芽に至るまでの胚の発達について調査し, GA 処理や果皮除去が肧の発達に及ぼす影響を調査した。さら に, 自生地におけるフェノロジーと栽培作型との比較, 検 討を行った。

\section{材料および方法}

\section{1. 島根半島を中心とした自生分布状況調査}

八マボウフウの自生分布については, 2004年7月から 2007 年 2 月に, 島根半島を中心とした島根県および鳥取県の海岸 地域で群落の有無や規模を調査した. 自生状況について, 多 数の個体が広範囲に自生集団を形成した場合は群落, 点在し た自生を確認した場合は自生確認として区別した。

\section{2. フェノロジー調査}

\section{1）自生地におけるフェノロジー観察}

自生地に打けるフェノロジ一は，打もに鳥取県米子市 弓ヶ浜海岸に自生する集団の約 30 個体について, 約 1 か月 ごとに茎葉の伸長や開花・結実の経過を調査した。なお， 調査個体については, 種子繁殖後に推定 3 年以上経過した 個体を対象とした。

\section{2）胚の発達調査}

植物材料として，2004 年 7 月 18 日に鳥取県米子市弓ヶ 浜海岸に自生する群落より採取した果実を, 白井ら（1999） の方法に従い天日で乾燥させた後に用いた.

果実の冷湿処理の方法は，村井・吉田（1991）の方法を 改良し，処理区として GA 処理および果皮の除去を組み合 わせた 4 処理区を設定した. GA 処理は殺菌剂（ベンレー 卜水和剤, 住友化学 (株) ) を加えた 3,000 ppm GA（ジべ レリン協和, 協和発酵 (株)) 水溶液に, GA 無処理では殺 菌剂を加えた蒸留水に, 24 時間浸漬した. これらの処理を 行った種子をポリエチレン製の袋に入れ， $3^{\circ} \mathrm{C}$ の冷蔵庫で 冷湿処理した. 冷湿処理期間は白井ら（1999）の報告に準 じて最長 90 日間とした.

冷湿処理期間中の胚の発達調査は, 冷湿処理 0 (対照区), $10 ， 20 ， 30 ， 40 ， 50 ， 60 ， 70 ， 80$ および 90 日目に各処理 区 10 粒の種子についてカミソリで縦断切片を作成し, 光学 顕微鏡を用いて観察した。肧乳長と臕長を測定した後, 嬉 野ら (2006)の方法に準じて肧長率 [(肧長／肧乳長 $) \times 100]$ を算出した.

播種後の肧の発達は, $22^{\circ} \mathrm{C}$ の室内において冷湿処理 90
日目まで 10 日ごとに各処理区 30 粒の種子をシャーレ内の 蒸留水で湿らせたろ紙上に播種し,播種 90 日目に前述と同 様に切片を作成し，観察を行った。

\section{結果および考察}

\section{1. 島根半島を中心とした自生分布状況調査}

本研究の調査で確認されたハマボウフウの自生地を第 1 図に示した。群落は鳥取県米子市弓ヶ浜海岸, 島根県大田 市五十猛海岸および江津市江の川河口付近から浜田市石見 海浜公園において確認された. 上記以外にも鳥取県米子市, 境港市弓ヶ浜海岸周辺, 島根県松江市御津, 出雲市大社町 稲佐の浜や外園海岸から湖陵町のほか, 島根県隠岐の島町 中村の海岸等でも自生が確認された。島根半島や島根県浜 田市以西では火山性の岩石海岸が多く，砂浜が少ないため 自生地がほとんどみられなかった。

群落が観察された米子市弓ヶ浜海岸や，群落が復帰しつ つある出雲市外園海岸の自生地では，乱獲防止の看板が設 置されていることから，地域の自生地保護活動の顕著な効 果が現れたことが示唆された。.八マボウフウは多年生植物 であり，自生地に扣いて根茎を掘り上げて調査を行ったと ころ，地表から約 $70 \mathrm{~cm}$ の深さまで垂直方向に地下茥を発 達させ，地表に近い根茎には多数の定芽が観察された（第 2 図)、春期に地上部の茥葉が採取された場合には，定芽か らの再生が可能であることから，現在，自生株の根茎が残 存している地域では，早急な自生地保護活動の推進が望ま れる. 外園海岸近隣の出雲農林高校では, 長浜地区の自治 団体と協力した自生地保護活動や，遺伝的多様性に配慮し た実生や in vitro 増殖種苗の自生地への定植に取り組んでい る. 今後のこれらの保護活動の発展と自生地の復帰が期待 される.

\section{2. フェノロジー調査 \\ 1）自生地におけるフェノロジー観察}

フェノロジー観察の結果を第2 図および第3 図に示した.

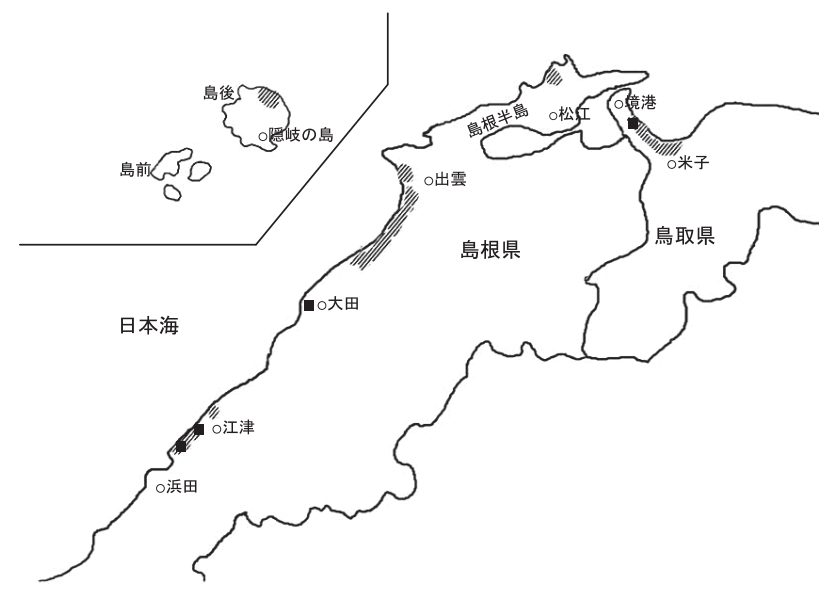

第 1 図島根半島周辺地域のハマボウフウの自生地

口: 群落（多数の個体が広範囲に自生集団を形成）

留：自生確認（点在した自生を確認） 

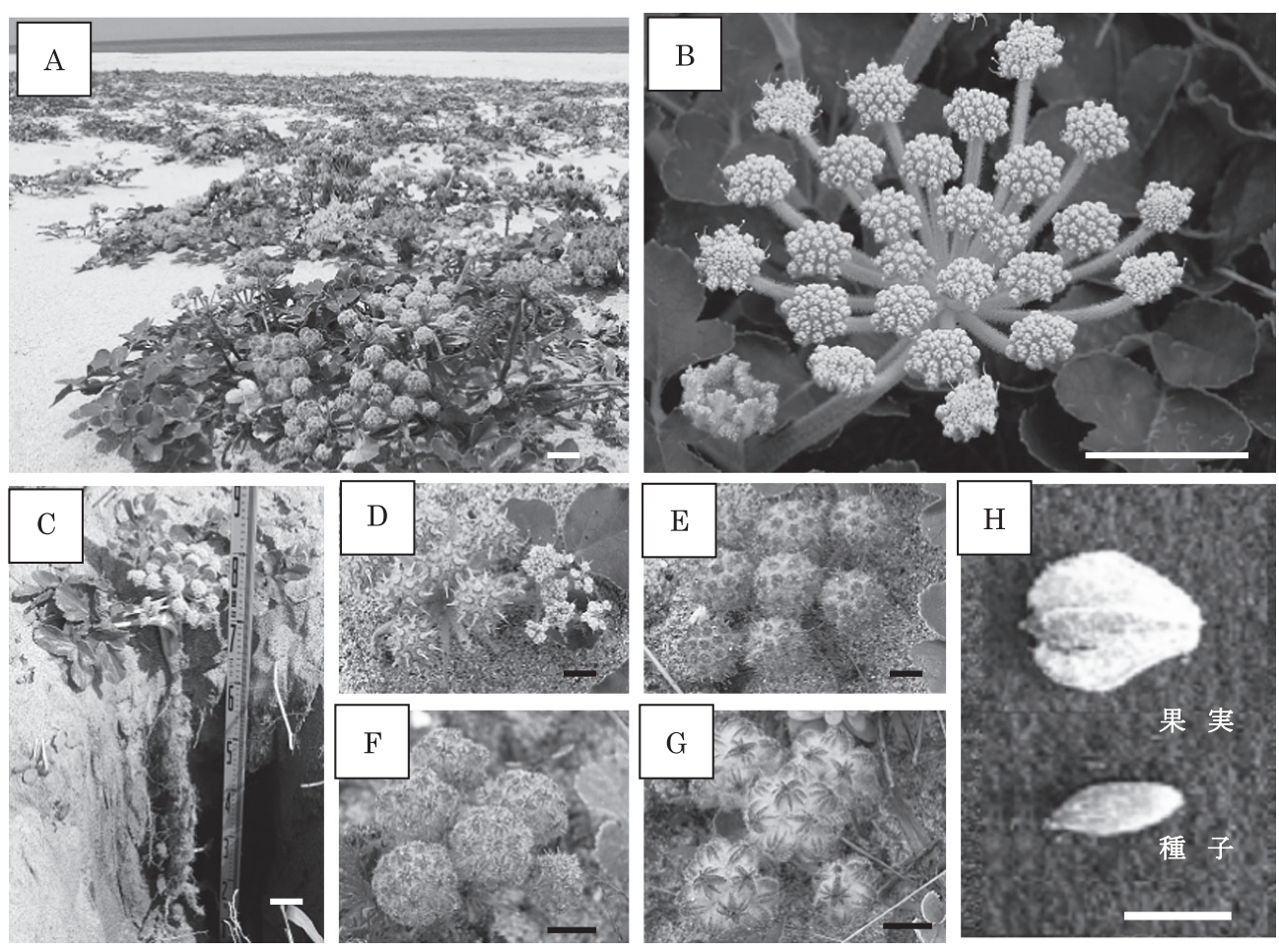

第 2 図 島根半島周辺地域に打けるハマボウフウの自生状況拈よび果実の発達

$\mathrm{A}$ ：自生地に打ける生育, B : 開花, $\mathrm{C}$ : 地上部と地下部, $\mathrm{D}-\mathrm{G}$ : 果実の発達, $\mathrm{H}$ : 採集した果実と種子,

一：A-C は $5 \mathrm{~cm}, \mathrm{D}-\mathrm{G}$ は $1 \mathrm{~cm}, \mathrm{H}$ は $5 \mathrm{~mm}$ を表す

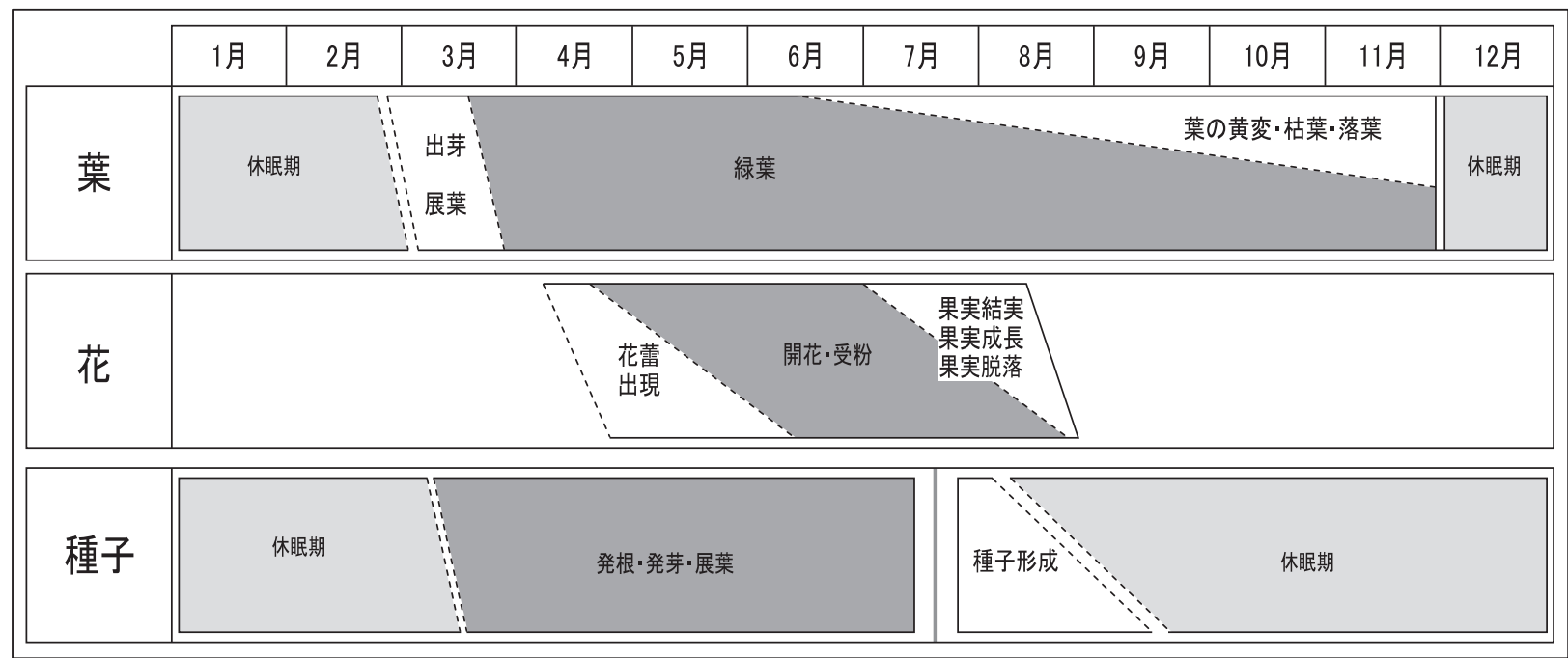

第 3 図 島根半島周辺地域のハマボウフウの自生地に打けるフェノロジー

2 月下旬以降に，休眠していた定芽の萌芽が開始し，地表 に接するように新葉が展開した. 新葉が複数枚展開した後, 4 月中旬から頂芽に花蕾が観察され, 5 月上旬から 8 月中旬 に複散形花序の白色の花が順次開花した。 7 月上旬からは 果実の発達, 成熟の観察に伴い葉の黄変や落葉がみられた. 完熟した果実は花柄から脱落し, 親株の周辺に落下したが, 8 月下旬以降には地表では観察されなかった。 果実は風に より飛散するが, 一部の果実は風によって堆積した砂中に
て，翌春まで休眠するためであると考えられる．9月以降 は葉の黄変や落葉が増加し，未開花の株等では秋期の展葉 も観察され, 気温の低下に伴い休眠に入る 12 月上旬まで緑 葉が維持された。一方，砂中にて休眠中の果実は翌春発芽 し，5月下旬から 6 月上旬に地表に小さな新葉を展開寸る 実生がみられた。

現在行われているハマボウフウの白茥軟化栽培では，露 地で播種後, 年内に育成した根株を 11 月下旬に掘り上げて 
ビニルハウス内の軟化床に伏せ込む．翌年の 1 月から 6 月 まで茎葉を収穫後, 7 月から 12 月まで株の養成を行い, 翌々 年に再び収檴する作型が採られている（成川，2001）。この 作型を自生地のフェノロジーと比べると，自生地では 2 月 下旬から 4 月頃まで茎葉が伸長するが，軟化栽培の作型で は 1 月から 6 月頃まで茎葉が伸長し, 収穫を行っている. 開花や結実については，自生地では新葉の展開が停止した 4 月以降に花芽が出現し, その後に結実するが, 栽培の作 型では花芽が形成されずに 4 月以降も茎葉の収穫を行って いる.これは軟化栽培では自生地と異なった環境条件に加 えて種苗が若齢であること,さらに出芽した茎葉を収穫期 間に数回摘久取るために花芽形成が抑制され，連続して茥 葉を展開するものと考兄られる。

現在，八マボウフウはほとんど品種分化していない，今 後，積極的な活用を考慮した場合に，年間を通して茎葉を 安定生産できるような新たな作型の開発とそれに適した品 種・系統の作出が期待される。また，開花から結実に至る までは茥葉が展開しないことから，結実による株の養分の 消耗を防き，株の養成を行らために三倍体を利用した不稔 系統作出と利用が, 茥葉の安定生産の一つの方法として有 望と考兄られる。

\section{2）胚の発達調查}

冷湿処理期間中の胚の発達に扔いて，肧長と肧乳長から 算出した肧長率を第 4 図に示した. 冷湿処理 10 日目以降の すべての処理区に扣いて冷湿処理期間が長くなるに従い肧 長率の上昇が認められ，冷湿処理により肧の発達が促進さ れることが確認された. 冷湿処理開始時に 10\%前後であっ た肧長率は，50日目以降に上昇を開始し，60日目からは $\mathrm{GA}$ 処理区は無処理区に比べ，果皮の有無に関わらず顕著 な上昇がみられた。また，果皮の有無については GA 無処 理の場合に 90 日目の果皮有り区の肧長率 $18 \%$ に対して, 果

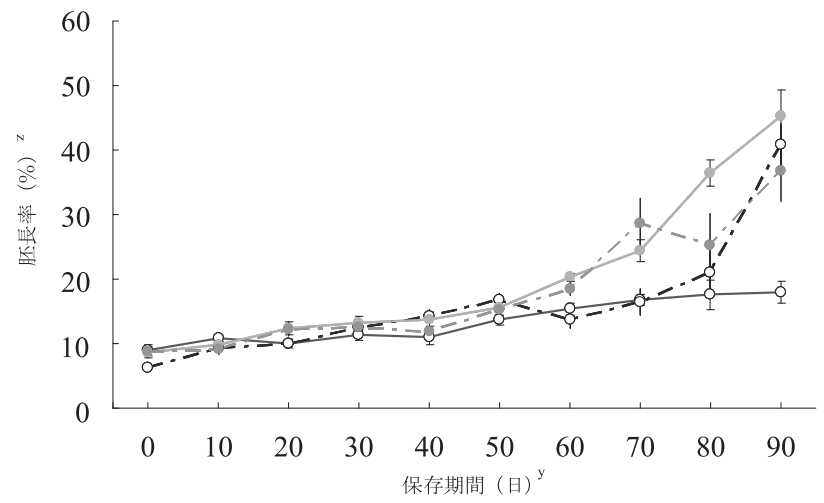

第 4 図 各処理区における冷湿処理後の肧長率の変化 ——: GA 無処理果皮有り区 - - - - - : GA 無処理果皮除去区 ——GA 処理果皮有り区 -... : GA 処理果皮除去区

${ }^{\mathrm{z}}$ 胚長率 $(\%)=($ 肧長 $/$ 胚乳長 $) \times 100$

$\mathrm{y}$ 冷湿処理温度 $3^{\circ} \mathrm{C}$

x 図中の縱線は標準䛊差を表す

皮除去区の胚長率が $41 \%$ あるあことから，果皮除去による 肧長率の上昇が認められた。な拉，採種日に比べて処理開 始時では肧長率が低下しているが，こ北は種子の乾燥によ る胚の縮小によるものと考兄られる。

さらに, 冷湿処理 90 日目の $\mathrm{GA}$ 無処理果皮有り区以外の 3 処理区では，胚長率が $40 \%$ 前後に上昇し，発根や種子中 の幼葉形成が観察されたことから，八マボウフウでは約 40 $\%$ の肧長率で発芽段階に移行することが示唆された.

一方，冷湿処理後に播種し，90 日目に胚の発達抒よび発 芽を調査したところ，果皮有り区では発芽がみられなかっ たが，果皮除去区では発芽や発根がみられた．GA 処理果 皮除去区の冷湿処理 90 日目では, 特に発芽や発根, 種子中 の幼葉形成が多く観察された（第 5 図）。また，冷湿処理を

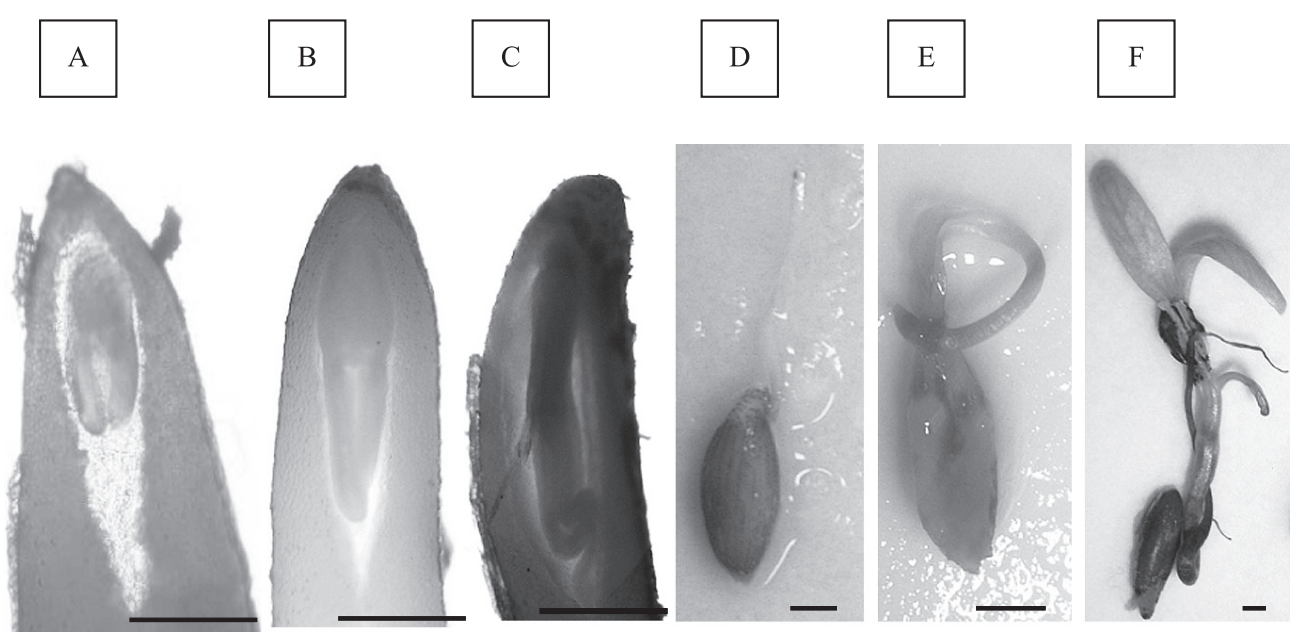

第 5 図 ハマボウフウ種子の胚および発芽に及ぼす冷湿処理の影響

A : 冷湿処理前の胚, B-C : 冷湿処理 90 日目に播種し，播種 90 日目にみられた胚（GA 処理果皮除去区),

D-F : 冷湿処理 90 日目に播種し，播種 90 日目にみられた発芽の様子（GA 処理果皮除去区）

— : A-C は $0.5 \mathrm{~mm}$, D-F は $2 \mathrm{~mm}$ を表す 
行わずに播種した種子（対照区）では， $\mathrm{GA}$ 処理果皮除去 区の夕に発芽がみられたことから，GA 処理括よび果皮除 去による肧の発達抢よび発芽の促進効果が認められた。

冷湿処理や GA 処理がハマボウフウ種子の発芽に及洔す 影響については, 果実の水浸漬後の低温処理が発芽期間を 短縮し, 発芽を斉一にする効果が高いこと（村井・吉田, 1991), 冬期に種子を土中にて貯蔵することにより発芽率が 向上すること（成川，2001）, 冷湿処理による種子の発芽促 進には GA 合成系の活性化が関与していること（白井ら， 1999）等が報告されている. 本研究の結果からも, 冷湿処 理や $\mathrm{GA}$ 処理は発芽扣よび胚の発達に効果があることが確 認された。 また, 肧の発達促進は冷湿処理温度が $3^{\circ} \mathrm{C} の$ 条 件下で処理後 50 日以降に久られることが明らかとなった.

本研究では果皮除去に上る胚の発達抏よび発芽の促進が みられた。 中村（1985）は, 種子の休眠の原因として果種 皮の機械的抑圧あるいはガス透過性の異常等以外に, 胚や 果種皮，頴類に含まれる抑制物質が原因となる場合が多い ことを指摘している．さらに，八マボウフウと同じセリ科 のニンジンでは, 発芽抑制物質として果皮中に carrotol と いら不溶性の抑制物質が含まれていること, 他のセリ科の コエンドロ，ウィキョウ，カミン抢よびCarum copticum の 種子でも水溶性の発芽抑制物質が含まれていることを報告 している. 八マボウフウの果皮除去による胚の発達打よび 発芽の促進効果は, 果皮に含まれる発芽抑制物質の除去に よるものと考兄られる.

\section{3. 自生地におけるフェノロジーと栽培作型との比較}

自生地のフェノロジーと栽培作型を比べると，自生する 八マボウフウは砂浜海岸という環境条件下に打いて, 植物 体の地上部に占める割合が大きな果実を形成した（第 2 図)。8月中旬以降では潘とんど生育は停止しているが，軟 化栽培では適宜，茎葉が收穫されることにより，1月から 6 月まで茎葉が伸長し続ける。 この作型では播種 2 年生の 株を使用することにより，種苗の生産性を高花芽形成の しにくい性質を利用していると考兄られる。な拈，この種 苗の生産に执いては 8 月前後に採種後, 翌春まで土中にて 貯蔵した種子を播種・育成している（成川，2001）。本研究 に抢ける肧の発達調査と自生地でのフェノロジーの結果か ら, 自生地では 12 月から 2 月の約 3 か月間の低温期遭遇 後, 3 月以降から種子の発芽や発根がみられた。 これらの ことから, 自生地においても冷湿処理に相当する環境が存 在し, 本研究に抢ける胚の発達は自生地でのフェノロジー と対応している結果であることが示唆された。

以上の上らに本研究から, 島根半島周辺地域に打梳る マボウフウの自生状況とそのフェノロジーについて明らか となった．また，休眠種子のフェノロジーに抢いては冷湿 処理打よび果皮除去による胚の発達和上び発芽の促進効果 が認められた. 本研究の結果は, 山陰地域の久ならず日本
各地のハマボウフウ自生地の保護活動の推進や地域特産遺 伝資源としての活用，栽培・増殖に打情基礎的な研究情 報となることが考光られる。

\section{摘 要}

八マボウフウの山陰地域に抢ける自生地の保護を推進 し, 地域特産資源として活用するための基礎研究として, 自生状況の調査とフェノロジ一観察ならびに冷湿処理下の 種子に打ける胚の発達について調查した，島根半島を中心 とした自生分布の調査に拈いて，鳥取県米子市弓ヶ浜海岸 や島根県浜田市石見海浜公園をはじめとする砂浜海岸で群 落が確認された．また，弓ヶ浜海岸や出雲市外園海岸では 自生地保護活動の効果が顕著に久られた。自生地における フェノロジ一観察の結果では, 2 月下旬以降の新葉の展開, 4 月中旬の花蕾の出現，5月上旬から 8 月中旬の開花，7月 上旬からの果実の発達, 成熟, 花柄からの脱落, 9 月以降 の葉の黄変や落葉，12月上旬からの休眠が観察された。 た, 休眠種子について冷湿処理 50 日以降に胚の発達がみら れ， $\mathrm{GA}$ 処理や果皮除去による胚の発達打よび発芽の促進 効果が認められた。

\section{引用文献}

青葉 高. 2000. 日本の野菜 青葉 高著作選 I. p. 190191. 八坂書房. 東京.

池羽智子・鹿島恭子. 2006. 県産野菜の抗酸化性の評価々 加熱調理による变化．茨城農総七園研報．14: 27-33.

伊藤晶子・佐々木 香・平岡 昇. 1996. 八マボウフウの 受粉様式について. 生薬学. 50: 303-305.

峰岸正好. 1989. 八マボウフウ.p. 12-13. 相賀徹夫編著.

園芸植物大事典. 4. 小学館. 東京.

村井正和・吉田俊郎. 1991. 八マボウフウ種子の発芽特性.

園学雑. 60 (別2) : 428-429.

中村俊一郎. 1985. 農林種子学総論. p. 57-63. 養賢堂. 東京. 成川 昇. 2001. 八マボウフウ. p. 197-205. 川城英夫編 著. 新 野菜つくりの実際 軟化・芽物一誰でもでき る露地・トンネル・無加温八ウス栽培一. 農文協. 東京. 日本の食生活全集鳥取編集委員会．1991．日本の食生活全 集31 聞き書 鳥取の食事. p. 82-83. 農文協. 東京. 小野蘭山. 1991. 本草綱目啓蒙 1. p. 195-197. 平凡社. 東京. 白井菊子 - 増田 清 - 田村春人 - 後藤真咲. 1999. 冷湿処

理，ジベレリン酸 $\left(\mathrm{GA}_{3}\right)$ 処理および泼の in vitro 培養 によるハマボウフウ（Glehnia littoralis Fr. Schmidt）種 子の発芽促進. 北大農研報. 31: 35-40.

嬉野健次・市川寛子・金澤俊成．2006。コシアブラ種子の 胚発育に及活す湿潤低温処理時期と期間および $\mathrm{GA}_{3}$ 処 理時期の影響. 園学研. 5: 369-374. 